УДК 371.3::811.163.41

811.163.41'35-057.874/.875

DOI: https://doi.org/10.18485/kij.2016.63.3_4.4

ГОРАН Н. ЗЕЉИТ

Учитељски факултет

Београд
Оригинални научни рад

Примљен: 01. 10. 2016.

Прихваћен: 21. 12. 2016.

\title{
ПРАВОПИСНА ЗНАЮА БУДУЋИХ УЧИТЕЉА И ВАСПИТАЧА
}

\begin{abstract}
У раду се анализирају резултати које су постигли кандидати на пријемним испитима на Учитељском факултету у Београду у периоду 2013-2014. на задацима из правописа српског језика. На узорку који је чинило укупно 1100 кандидата на два пријемна испита на оба смера (учитељском и васпитачком) биће испитано у којој мери свршени средњошколци који су радили тест из српског језика и књижевности познају књижевнојезичку норму. Истраживањима овог типа успоставља се веза између учења правописних правила и утицаја говорне и писане праксе говорника једног језика. Анализа грешака показала је да свршени средњошколци имају проблема када треба да примене више правописних правила у једном ширем контексту какав је реченица. Резултати истраживања указују на потребу да је неопходно изменити приступе садржајима правописа на свим узрасним нивоима померањем фокуса са упознавања и примене појединачних правописних правила на развијање дубљег разумевања и повезивања различитих компоненти правописних знања.
\end{abstract}

Кључне речи: српски језик, настава српског језика, правописна норма, правопис.

1. О језичкој култури је доста писано и са лингвистичког и са интердисциплинарног аспекта (в. Брборић et al. 1982; Васић et al. 1998; Шипка 2011). Место и циљеви језичке културе у образовном процесу давно су утврђени, указано је на проблеме који притом настају, смернице и опште карактеристике (Васић et al. 1998; Косановић 2002). Када говоримо о језичкој култури наших ученика и студената, мислимо у ствари на степен познавања књижевнојезичке норме. В. Брборић наглашава да се „основни елементи говорне културе огледају у ортографији и ортоепији, тј. усаглашавању говорне и писане речи са нормативним захтевима фонетике, морфологије, синтаксе и лексике” и да „без ваљаног усвајања ових правила књижевног језика нема добре и потпуне језичке културе" (Брборић 1998: 519). Поред тога, на правилност говора утичу различити чини-

"goran.zeljic@uf.bg.ac.rs 
оци, међу којима су школска настава и средства јавног информисања (Шипка 2011: 100). У новијим истраживањима на различитим школским нивоима који су посвећени овој теми (Брборић 2004; 2010; Стевановић 2009; 2011; 2012) указује се на то да је потребно унапредити културу писменог изражавања и то не само појединаца већ и целе језичке заједнице (Стевановић 2011: 650). У испитивањима која су посвећена утврђивању степена писмености одређеног дела популације (у овом случају ученичке) не сме се изгубити из вида и утицај који писана пракса има. У неколико радова (Зељић 2007; 2008; Чорболоковић 2015) истичу се правописна огрешења у пракси с циљем да се она искористе при учењу и примењивању одређеног правописног правила, али и при стварању својеврсне картотеке најчешћих правописних огрешења која морају бити обрађена у наставној пракси (Зељић 2004), и која представљају оно што је Т. Прћић назвао паралелном обичајном нормом која истискује ону прописану и тако нарушава њен примат (Прћић 2003: 18). У данашњим уџбеницима српског језика (нпр. Прћић 2006), већ од млађег школског узраста, можемо наћи и правописне речнике (познато „није - него”), као и у оквиру лекција ученицима блиске примере супстандарда, управо с циљем да се поспеши њихова језичка култура. Међутим, и поред добре уџбеничке литературе, обучених наставника, резултати су незадовољавајући (Стевановић 2011: 639).

2. Предмет овог истраживања јесте познавање правописних правила код свршених средњошколаца који су у оквиру пријемног испита радили тест из српског језика и књижевности на Учитељском факултету Универзитета у Београду у академској 2013/2104. и 2014/2015. години.

3. Циљ истраживања био је да се испита учесталост и врста грешака које су кандидати чинили у области правописа (велико почетно слово, гласовне алтернације и сл.) на пријемном испиту.

4. За потребе истраживања из тих тестова издвојена су укупно три задатка која су се односила на правопис српског језика, и то са првог теста један задатак, а са другог теста два задатка. Задаци су отвореног и затвореног типа, а испитивано је:

1. Преписивање реченице уз примену правописних правила

2. Употреба великог почетног слова

3. Гласовне алтернације

4. Узорак истраживања чинило је 1100 кандидата (по годинама 2013/14. 562 и 2014/15. 538 кандидата) ${ }^{1}$ на пријемном испиту на оба смера (учитељском и васпитачком).

${ }^{1}$ Академске 2013/14. на смеру за образовање учитеља 261, а за образовање васпитача 301 кандидат, а 2014/15. са учитељског смера учитеља 256, а са васпитачког 282 кандидата. 


\section{Анализа и интерпретација резултата истраживања}

Прво ћемо анализирати грешке које су настале приликом преписивања реченице уз примену правописних правила (велико почетно слово, интерпункција, спојено и одвојено писање речи).

1. Знања која се односе на већи број правописних правила испитивана су на следећем задатку из 2013. године:

Напишите правилно следећу реченииу водећи рачуна о правопису:

ДА БИ СМО КУПИЛИ РОМАН ВЕЛИКИ РАТ АЛЕКСАНДРА ГАТАЛИЦЕ ОТИШЛИ СМО КНЕЗ МИХАИЛОВОМ УЛИЦОМ У КЮИЖАРУ ПЛАТО.

У табели која следи приказан је однос тачних и нетачних одговора укупно. Одговор је тачан уколико је цела реченица преписана у складу са правописном нормом.

Табела 1. Однос тачних и нетачних одговора на задатак у цуелости

\begin{tabular}{|l|c|c|}
\hline Задатак & Број кандидата & \% \\
\hline $\begin{array}{l}\text { Реченица преписана у складу } \\
\text { с стандарднојезичком нормом }\end{array}$ & 91 & 16,19 \\
\hline Са грешком/грешкама/недовршено & 471 & 83,81 \\
\hline Укупно & 562 & 100 \\
\hline
\end{tabular}

Грешке које смо нашли у одговорима тицале су се 1 . лица једнине аориста глагола бити, великог почетног слова у називу улица, књижевних дела и установа, те интерпункције (запета).

\section{1. Аорист помоћног глагола бити у 1. л. мн.} (област Спојено и одвојено писање речи)

Прва област која је увршћена у реченицу јесте питање писања глагола бити у аористу као делу потенцијала. Кандидатима је понуђен супстандардни облик би смо. Однос тачних и нетачних одговора приказан је у табели која следи. 
Табела 2. Однос тачних и нетачних одговора у вези са 1. л. јд. аориста гл. бити

\begin{tabular}{|l|c|c|}
\hline 1. л. јд. аориста гл. бити & Број одговора & \% \\
\hline би смо & 233 & 49,47 \\
\hline бисмо (тачан одговор) & 236 & 50,11 \\
\hline бих смо & 2 & 0,42 \\
\hline Укупно & 471 & 100 \\
\hline
\end{tabular}

Грађење сложених глаголских облика обрађује се веома рано, још на млађем школском узрасту (Наставни програм за први и други разред), и то од три најфреквентнија глаголска облика два су сложена - перфекат и футур I. Увођење осталих сложених глаголских облика у старијим разредима (у петом разреду ОШ плусквамперфекат, потенцијал, футур II; Наставни програм за пети разред) базирано је на основама које су успостављене на млађем школском узрасту, када се морфолошки аспект већ тада повезује са синтаксичким (функција помоћног глагола у оквиру именског предиката) и правописним аспектом (грађење футура I од глагола који се у инфинитиву завршавају на -ћu типа доћu: доћи ћу/ћy доћи насупрот глаголима на -ти типа певати: певаћу/ћу певати). И управо тај правописни аспект у првом је плану када се обрађује потенцијал. Наиме, у пракси се јавља више огрешења која називамо правописним а у ствари су морфолошка. Тако је данас сасвим уобичајено рећи ја би дошао/ми би дошли, где се аналогно у свим лицима употребљава $2 / 3$. лице једнине аориста глагола бити за сва остала лица оба броја. Нешто ближи нормираном, али опет у оквиру супстандарда, јесу примери растављеног писања облика за 1. и 2. лице множине би смо и би сте (ум. бисмо/бисте). Управо то супстандардно решење дато је и у задатку, али га је кориговао мали број кандидата (свега нешто више од 50\%), из чега можемо закључити да би тај проценат био и нижи да је стајао супстандардни облик би за ово лице. Неопходно је, дакле, уврстити питање грађења овог облика у сам врх обавезних огрешења која се јављају у пракси, а која се могу отклонити и обрадом са више аспеката (морфолошком и правописном), али и на основу грешака које се уочавају у пракси и које су ученицима блиске (Зељић 2007; 2008; Чорболоковић 2015).

\section{2. Назив књижевног дела, улице и установе (област Велико почетно слово)}

Због великог броја различитих грешака, у табелама је дат број одговора са тачним решењем и број одговора са типичним грешкама. 
Табела 3. Однос тачних и нетачних одговора у вези са називом књижевног дела

\begin{tabular}{|l|c|c|}
\hline Назив књижевног дела & Број одговора & \% \\
\hline „Велики рат” (тачан одговор) & 305 & 64,76 \\
\hline Велики рат/(,)Велики Рат(”)/”Велики рат” & 166 & 35,24 \\
\hline Укупно & 471 & 100 \\
\hline
\end{tabular}

Табела 4. Однос тачних и нетачних одговора у вези са називом улице

\begin{tabular}{|l|c|c|}
\hline Назив улице & Број одговора & \% \\
\hline Кнез Михаилова улица (тачан одговор) & 299 & 63,48 \\
\hline $\begin{array}{l}\text { Кнез-Михаилова улица/кнез Михаилова ули- } \\
\text { ца/кнез Михаилова Улица/ } \\
\text { „нез Михаилова улица"/ Кнез Михајлова } \\
\text { улица }\end{array}$ & 172 & 36,52 \\
\hline Укупно & 471 & 100 \\
\hline
\end{tabular}

Табела 5. Однос тачних и нетачних одговора у вези са називом предузећа

\begin{tabular}{|l|c|c|}
\hline Назив предузећа & Број одговора & $\mathbf{\%}$ \\
\hline „Плато” (тачан одговор) & 190 & 40,34 \\
\hline Плато/„Плато”/,Плато” & 281 & 59,66 \\
\hline Укупно & 471 & 100 \\
\hline
\end{tabular}

Сва три задатка спадала су у правописну област Употреба великог почетног слова. И ова правописна област обрађује се на млађем школском узрасту, већ у првом разреду, почев од писања почетка реченице (Наставни програм за први и други разред). Једна од битнијих тема које се тада обрађују јесте и писање назива улица (други разред). У нашем задатку показало се да су се у одговоре кандидата неоправдано мешала и друга питања, као што су писање титула, наводника, те, изненађујуће, и писање графеме $j$ у именици Михаило (Михајло). Управо су и ове три грешке оне грешке које су се јављале у одговорима, с тим што бисмо прво истакли писање назива улице малим почетним словом, по погрешној аналогији да се титуле пишу малим почетним словом, те употребу наводника, 
опет по аналогији са обележавањем наслова књига, часописа, друштава, хотела и сл. У задатку је избегнута дилема која би настала да је као пример узет назив који у себи на првом месту има именицу улица, већ је кандидатима сугерисано да је именица кнез прва реч у називу, те је било очекивано да тако дилеме нема, међутим, резултати показују да је велики број кандидата писао мало почетно слово ове именице.

Други део овог задатка који је спадао у област употребе великог почетног слова, али и писање наслова књижевних/уметничких дела и назива установа/ предузећа, јесте и писање наводника уз те називе. Уместо исправног назива „Велики рат”, односно „Плато”, кандидати су правили сада већ уобичајене грешке које су резултат утицаја енглеског (и нешто мање немачког језика). Наиме, или су обе речи у називу књижевног дела биле са великим почетним словом, или су почетни знаци навода за оба назива били написани у горњем делу речи. Уз ово огрешење, кандидати су после назива књижаре „Плато”, која је била последња реч у реченици, тачку писали унутар наводника (18 примера од 471), што правопис прописује само када је у питању реченица (Пешикан et al. 2010: 134).

\section{3. Обележавање намерне реченице у инверзији (област Интерпункција)}

Запета је најобрађенији правописни/интерпункцијски знак. О њој је исцрпно писала и Душка Кликовац (Кликовац 2011а; Кликовац 2011б), а у настави се обрађује опет веома рано, у другом разреду ОШ (Наставни програм за први и други разред).

Иако је наша интерпункција слободна (логичка), код употребе запете (зареза) постоје ситуације када се она мора употребити јер се тако обележава „напоредност, накнадно додавање, супротност, нарочито истицање” (П1960: 91), односно реченична инверзија (Пешикан et al. 2010: 101)². Од већег броја ситуација у којима се запета употребљава, у основношколским граматичким приручницима најчешће се издваја употреба запете у набрајању и између реченица независних, главних и зависних.

У нашем задатку употребљена је намерна зависна реченица у инверзији. Дакле, реч је о једном „школском примеру”, јер се још приликом обраде сложених реченица утврђује правило да се она може састојати од више независних или од главне и једне или више зависних реченица. Тада се констатује да је уобичајено да зависна реченица стоји после главне јер оне допуњују или ближе одређују друге реченице или речи, те тада „природа њихове зависности, доиста, обично и не допушта стављање зареза између зависних и главних реченица. Али, на првом месту, ред којим иду главне и зависне реченице није увек исти, а променом њихова реда на неки се начин мења и однос међу њима" (П1960: 101). Тада говоримо о инверзији - „тј. обрнутом реду, када, наиме, зависне долазе

\footnotetext{
${ }^{2}$ Истичемо оба правописна приручника да бисмо показали да је норма у овом смислу давно утврђена и да до промена није дошло у савременом стандардном језику.
} 
испред главних реченица”, па се запета између њих мора увек писати (П1960: 108).

На овом задатку забележен је највиши проценат тачних одговора $(86,84 \%)$, јер је у 409 од 471 рада била написана запета.

Табела 6. Однос тачних и нетачних одговора у вези са употребом запете у обележавању инверзије

\begin{tabular}{|l|c|c|}
\hline Обележавање намерне реченице у инверзији & Број одговора & \% \\
\hline Са запетом (тачан одговор) & 409 & 86,84 \\
\hline Без запете & 62 & 13,16 \\
\hline укупно & 471 & 100 \\
\hline
\end{tabular}

У овом задатку обухваћене су све битне правописне области које се обрађују још на млађем школском узрасту. Зато забрињава веома мали број тачних одговора у целости (свега 16\%), што нам даје за право да констатујемо да наши свршени средњошколци нису савладали наведене правописне области тако да стечена знања могу применити у ширем контексту какав је реченица. Резултати нашег истраживања блиски су и резултатима до којих је дошла Стевановић (Стевановић 2012) такође на реченици (успешност 9,2\%). Испада, тако, да је овакав задатак на било којој врсти провере задатак који спада у теже, с великом могућношћу да постане претежак, па тако и неселективан. Међу грешкама које су се јављале налазили смо и реченице које немају велико почетно слово на њеном почетку (6 тестова, 1,07\%), често је изостајала и тачка на крају (32 теста, 5,69\%), тачка се јављала унутар наводника (у склопу назива „Плато”; 13 тестова, 2,31\%), уместо аориста бисмо јавило се и решење бих смо (2 теста, 0,42\%) итд., што спада у врсту правописних огрешења која нису била очекивана на овом ученичком узрасту. И број учињених грешака није занемарив. Већина анализираних одговора у том задатку имала је више грешака, најчешће, као што смо видели, у употреби наводника у називу књижаре. Тако је од 471 кандидата који нису добро урадили задатак у целости, највише кандидата чинило по две грешке у преписивању реченице (184 кандидата; 39,07\%), затим по једну $(145 ; 30,78 \%)$, три $(112 ; 23,78 \%)$, четири $(19 ; 4,03 \%)$, пет $(7 ; 1,49 \%)$, шест $(4 ; 0,85 \%)$.

2. Функционална знања о писању великог почетног слова у вишечланим називима испитивана су на следећем задатку са теста из 2014. године:

Подвуичите исправно написане историјске догађаје:

Велики Рат

Први Балкански рат

први Српски устанак
Велики рат

први Балкански рат

Први српски устанак велики рат

Први балкански рат

први Српски Устанак 
Успешност кандидата на задацима у целини и на појединачним примерима представљен је у табелама 7 и 8.

Табела 7. Однос тачних и нетачних одговора на задатак у цуелости

\begin{tabular}{|l|c|c|}
\hline Вишечлани назив историјског догађаја & Број кандидата & \% \\
\hline Сва три тачна одговора & 268 & 49,81 \\
\hline Погрешан барем један одговор & 270 & 50,19 \\
\hline Укупно & 538 & 100 \\
\hline
\end{tabular}

Табела 8. Однос тачних и нетачних одговора на називе појединачно

\begin{tabular}{|c|c|c|c|}
\hline \multicolumn{2}{|c|}{ Вишечлани назив историјског догађаја } & Број одговора & $\%$ \\
\hline \multirow{4}{*}{ ВЕЛИКИ РАТ } & Велики Рат & 40 & 7,43 \\
\hline & Велики рат (тачан одговор) & 458 & 85,14 \\
\hline & велики рат & 40 & 7,43 \\
\hline & Укупно & 538 & 100 \\
\hline \multirow{4}{*}{$\begin{array}{l}\text { ПРВИ } \\
\text { БАЛКАНСКИ } \\
\text { РАТ }\end{array}$} & Први Балкански рат & 189 & 35,13 \\
\hline & први Балкански рат & 29 & 5,39 \\
\hline & $\begin{array}{l}\text { Први балкански рат } \\
\text { (тачан одговор) }\end{array}$ & 320 & 59,48 \\
\hline & Укупно & 538 & 100 \\
\hline \multirow{4}{*}{$\begin{array}{l}\text { ПРВИ } \\
\text { СРПСКИ } \\
\text { УСТАНАК }\end{array}$} & први Српски устанак & 37 & 6,88 \\
\hline & $\begin{array}{l}\text { Први српски устанак } \\
\text { (тачан одговор) }\end{array}$ & 476 & 88,47 \\
\hline & први Српски Устанак & 25 & 4,65 \\
\hline & Укупно & 538 & 100 \\
\hline
\end{tabular}

У задатку је испитивано да ли кандидати познају правило о употреби великог слова у писању назива историјских догађаја. У сва три примера није било властитих именица унутар назива, па се очекивало да кандидати констатују да је реч о сродним примерима, примерима који представљају званичне називе историјских догађаја и да сва три имају само велико почетно слово прве речи. 
За испитивање коришћена су три важна историјска догађаја за српску историју, што је требало да допринесе и већем броју тачних одговора. И овде имамо неуједначен однос тачних и погрешних одговора у целости и појединачно за сваки назив. У Табели 7 видимо да је само нешто мање од половине кандидата урадило задатак у целости. Међутим, ако се погледају појединачни одговори, за називе Велики рат и Први српски устанак, велики број кандидата заокружио је управо ова решења као тачна (у оба случаја од 85\% до 89\%), те за назив Први балкански pam нешто мање (око 60\%). Наиме, тест је рађен у години обележавања стогодишњице почетка Великог рата (Првог светског рата), па је било и очекивано да су се кандидати у школској и општој пракси сусрели са овим називом. То се може констатовати и за Први српски устанак као назив познатог и у наставној пракси обрађеног историјског догађаја. Проблем за кандидате представљао је назив Први балкански рат, где је више од 40\% кандидата редни број рата, не повезујући то са Првим српским устанком, тј. не правећи аналогију са датим примером, третирало као нешто што није део званичног назива историјског догађаја, те је придев балкански имао велико почетно слово.

Друга огрешења која су се јавила у задатку последица су ненаученог правила о писању вишечланих назива. Од наставника̂ (било учитеља̂, било наставника̂ српског језика) очекује се да приликом обраде великог почетног слова посебну пажњу усмере на вишечлане називе систематизујући их у две посебне групе - a) вишечлане називе континената, држава, градова и села - имају почетно велико слово свих речи (без обзира на број речи) и б) остале називе (мора, река, језера, планина, улица, делова града, историјских догађаја и сл.), који имају само почетно велико слово прве речи и осталих само уколико су властита имена. То се ради већ на првом кораку - на млађем школском узрасту. За боље резултате и за боље схватање и прихватање правила наставник може користити и огрешења из праксе (в. Чорболоковић 2015), али и аналогију (в. Милановић 2012).

3. Познавање гласовних алтернација проверавано је на задатку који је такође био на тесту из 2014. године:

Напишите, поштујући правописна правила, именице које се творе са следећим префиксима:

$$
\begin{array}{ll}
\text { под }+ \text { сукња }, & \text { под + коленица } \\
\text { пред + иколац } & \text { пред + час }
\end{array}
$$

У задатку треба применити правило које се везује за најчешћу алтернацију у српском језику - алтернацију звучних и безвучних сугласника у додиру и изузетак од тог правила. Белићевим правописом ${ }^{3}$ (у употреби од 1923. до 1960. год.) било је предвиђено да до алтернације $\partial: m$ долази и испред безвучнога сугласника $c$, да би се почев од Матичиног правописа 1960. године примењивало правило

\footnotetext{
${ }^{3}$ Претседник, претсобље (из 1923. године, в. Белић 1999: 127). Међутим, у Политиции из 1928 бележимо и следећи пример: У комисији су се међутим одмах запазиле велике супротности међу француским и енглеским представницима (Политика, 01. 10. 1928:1).
} 
да ће изостати алтернација $\partial: m, \hbar: \hbar$ ако се иза звучних сугласника $\partial$ и $ђ$ нађу безвучни сугласници $c$ и $u$. Са примерима примене овог правила ученици се срећу чим овладају читањем и писањем, нпр. већ у буквару (нпр. у песми Јесен на пијаци у стиху „Просто брдско цвеће/нико га неће”, в. Милатовић-Ивковић 2003: 77), да би се са самим правилом упознали у четвртом ${ }^{4}$ разреду. Иако је, дакле, реч о правилу које представља основни изузетак од најчешће гласовне алтернације у нашем језику, у пракси то је правило са највише огрешења (Зељић 2008). Очекивано је било, зато, да ће број тачних одговора бити велики, те да ће проценат задатака урађених у целости бити висок. Међутим, показало се да свега $24 \%$ кандидата зна да примени правило водећи рачуна и о изузетку (Табела 9).

Табела 9. Однос тачних и нетачних одговора на задатак у целости

\begin{tabular}{|l|c|c|}
\hline Префикс + творбена основа & Број кандидата & $\mathbf{\%}$ \\
\hline Сви тачни одговори & 130 & 24,16 \\
\hline Погрешан барем један одговор & 386 & 71,75 \\
\hline Непопуњено & 22 & 4,09 \\
\hline Укупно & 538 & 100 \\
\hline
\end{tabular}

У задатку су дата два префикса (под- и пред-) чији финални глас је звучни сугласник $\partial$. Дакле, требало је водити рачуна о томе када ће до алтернације звучног сугласника $\partial$ са безвучним сугласником $m$ доћи а када не. Конкретно, до алтернације је требало доћи у примерима потколеница и претчас, а она би изостала у примерима подсукњ $а$ и предиколаи, јер се звучни сугласник $\partial$ налази испред безвучних сугласника $c$ и $m$. Однос тачних и нетачних одговора дат је у Табели 10. У нетачне одговоре, нажалост, сврставани су и одговори у којима су кандидати уместо префикса под- користили префикс над- (вероватно због фонта Times New Roman и графеме п ( $n$ ) у италику), дајући у ствари тачне облике надсукња (4 одговора) и натколенииа (5 одговора). Најмањи број тачних одговора забележен је у облику речи претчас. Наиме, само $39,15 \%$ кандидата написало је нормиран облик претчас, док су се као нетачни одговори јављали и облици предчас $(43,22 \%$, без алтернације) и пречас $(17,63 \%$, са алтернацијом $\partial: m$ и губљењем сугласника).

${ }^{4}$ У оквиру ортоепије, нпр. при изговору придева људски (Наставни програм за четврти разред), односно у оквиру фонетике (гласовне промене и алтернације) у шестом разреду (Наставни програм за шести разред). 
Табела 10. Однос тачних и нетачних одговора појединачно

\begin{tabular}{|c|c|c|c|}
\hline \multicolumn{3}{|c|}{ Префикс + творбена основа } & \multirow[b]{2}{*}{$\%$} \\
\hline & & $\begin{array}{c}\text { Број } \\
\text { одговора }\end{array}$ & \\
\hline \multirow{5}{*}{ под + сукња } & подсукња (тачан одговор) & 366 & 70,93 \\
\hline & потсукња & 145 & 28,10 \\
\hline & надсукња & 4 & 0,78 \\
\hline & натсукња & 1 & 0,19 \\
\hline & укупно & 516 & 100 \\
\hline \multirow{5}{*}{ под + коленица } & потколеница (тачан одговор) & 394 & 76,36 \\
\hline & подколеница & 108 & 20,93 \\
\hline & надколеница & 5 & 0,97 \\
\hline & натколеница & 9 & 1,74 \\
\hline & укупно & 516 & 100 \\
\hline \multirow{4}{*}{ пред + школарац } & предшколац (тачан одговор) & 446 & 86,43 \\
\hline & претшколац & 63 & 12,21 \\
\hline & прешколац & 7 & 1,36 \\
\hline & укупно & 516 & 100 \\
\hline \multirow{4}{*}{ пред + час } & претчас (тачан одговор) & 202 & 39,15 \\
\hline & предчас & 223 & 43,22 \\
\hline & пречас & 91 & 17,63 \\
\hline & укупно & 516 & 100 \\
\hline
\end{tabular}

Огрешења у вези са гласовима $\partial$ и с/и иду у три правца (Зељић 2008: 1): 1) алтернација се врши; 2) нема алтернације кадгод се сугласник $\partial$ нађе испред било ког безвучног сугласника ${ }^{5}$ и 3 ) нема алтернације било ког звучног сугласника испред безвучног сугласника $c^{6}$. Указивањем на такве појаве утврђује се правило и спречавају се ,лутања” којих у говорној и писаној пракси има превише.

${ }^{5}$ Нпр.: Уплатнице неће бити обједињене, а рокови за плаћање исти су као и за предходне рачуне (Вечерње новости, 28. 7. 2007: 19).

${ }^{6}$ Клубска музика Филмски град, Кнеза Вишеслава 88, 11030 Чукарица (http://www.zute-strane1. rs/klubska-muzika-beograd-filmski-grad-\%7C-restoran-filmski-grad), 15. 07. 2015. 


\section{Закључак}

1. Урађена анализа показује да свршени средњошколци имају потешкоћа када треба да примене више правописних правила у једном ширем контексту какав је реченица. Разуме се да лошијим резултатима доприноси и број захтева унутар тог задатка, чиме се повећава могућност да се погреши. Ипак, у настави овај начин провере знања из правописа је уобичајен имајући у виду наставне и ваннаставне материјале који се користе у основној и средњој школи (Дудварски-Филиповић 2011: 66; Кликовац 2008: 199; Вељковић-Станковић 2015: 157; Ломпар 2012: 125), а што је примењено и у истраживањима (Стевановић 2012). Добијени резултати упућују на то да је неопходно развијати дубље разумевање и повезивање различитих компоненти правописних знања на свим узрасним нивоима. Коначно, добар начин да се правописна правила савладају јесте и учење на грешкама, што би подразумевало да се примери огрешења укључе у наставну праксу на свим нивоима. Тако би већ на млађем школском узрасту ученици сами налазили нормативна огрешења у својој околини (почев од назива улица, попут оних у Београду као што су Пећска, Хиљадутриста каплара или Љубићска у Чачку, Шумадиска у Крагујевцу, Драгчета Миловановића у Нишу, 7 јула у Новом Пазару и сл.).

2. Након овакве анализе не може се говорити о степену писмености (у смислу поштовања правописне норме) наших свршених средњошколаца - будућих учитеља и васпитача. Ипак, наведени резултати могу бити један од показатеља да су наши ученици недовољно овладали правописним знањима, те да је нужно повећати удео правописа и правописних вежби у настави српског језика у средњој школи. Отворено питање за будућа истраживања јесте и питање обраде правописних правила и врста правописних вежби у уџбеничкој литератури.

\section{ЛИТЕРАТУРА}

Белић 1999: А. Белић, Правописи, књ. 1 и 2. Београд: Завод за уџбенике.

Брборић et al. 1982: Брборић, Б. (прир.), Актуелна питања наше језичке културе, Зборник радова, Београд: Просветни преглед.

Брборић 2004: В. Брборић, Правопис српског језика у наставној пракси, Београд: Чигоја штампа.

Брборић 2011: В. Брборић, Правопис и школа, Београд: Друштво за српски језик и књижевност Србије.

Bacuћ et al. 1998: С. Васић, У. Кисић, М, Даниловић (прир.), Језик и култура говора у образовању, Београд: Институт за педагошка истраживања и Завод за уџбенике и наставна средства. 
Вељковић-Станковић 2015: Д. Вељковић Станковић, Тестови из српског језика, Београд: Друштво за српски језик и књижевност.

Дудварски, Филиповић 2011: М. Дудварски, 3. Филиповић, Објашњењ а и вежбана за боље оиене у осмом разреду, Београд: Klett.

Зељић 2004: Г. Зељић, Језичка култура у образовању, Педагогија, 1, 121-127.

Зељић 2007: Г. Зељић, Правопис српског језика у разредној настави, у: И. Радовановић, Б. Требјешанин (ур.), Дидактичко-методички аспекти промена у основношколском образовању (75-88), Београд: Учитељски факултет.

Зељић 2008: Г. Зељић, Правописни аспект гласовних промена у млађим разредима основне школе, у: И. Радовановић, Б. Требјешанин (ур.), Иноваиије у основношколском образовању - од постојећег ка могућем (264-275), Београд: Учитељски факултет.

Зељић 2009: Г. Зељић, Правописни речник у настави и уџбеницима српског језика, у: И. Радовановић, Б. Требјешанин (ур.), Иновације у основношколском образовању - вредновање (297-308), Београд: Учитељски факултет.

Кликовац 2008: Д. Кликовац, Збирка задатака из граматике српског језика за основну школу, Београд: Српска школска књига.

Кликовац 2011а: Д. Кликовац, О обради запете у новом издању Правописа српскога језика, Књижевност и језик, 1-2, 115-124.

Кликовац 2011б: Д. Кликовац, О обради интерпункције у старом и новом издању Правописа српскога језика, Кюижевност и језик, 3-4, 229-248.

Косановић 2002: Ј. Косановић, Говорење и култура у говору и језику, Норма, 1-2, 101-107.

Ломпар 2012: В. Ломпар, Граматика, уибеник за први разред гимназија и средњих стручних школа, Београд: Klett.

Милановић 2012: А. Милановић, Значај аналогије у настави српског језика, Кюижевност и језик, 1-2, 107-118.

Милатовић, Ивковић 2003: В. Милатовић, А. Ивковић, Буквар за први разред основне школе, Београд: Завод за уџбенике и наставна средства.

Наставни програми за $1,2,3,4,5$. и 6. разред, http://www.zuov.gov.rs/ poslovi/nastavni-planovi/nastavni-planovi-os-i-ss/ 21. 03. 2016.

Пешикан et al. 2010: М. Пешикан, J. Јерковић, М. Пижурица, Правопис српскога језика, Нови Сад: Матица српска.

Правопис 1960: Правопис српскохрватскога књижевног језика са правописним речником (израдила правописна комисија), Нови Сад - Загреб: Матица српска - Матица хрватска.

Прћић 2006: Љ. Прћић, Језичке поуке, приручник за 2. разред основне школе, Београд: Едука.

Прћић 2003: Т. Прћић, *Предлози За Нови Правопис (3): Псеудо Норма Несме Победити!*, Језик данас, 17, 18. 
Стевановић et al. 2009: Ј. Стевановић, С. Максић, Л. Тењовић, О писменом изражавању ученика основне школе, Зборник Института за педагошка истраживаға, 1, 147-164.

Стевановић 2011: J. Стевановић, Правописне одлике језичке културе ученика у основној школи, Српски језик, 1-2, 637-652.

Стевановић 2012: Ј. Стевановић, Правописна норма у средњошколској наставној пракси, Настава и васпитање, 1, 7-21.

Чорболоковић 2015: С. Чорболоковић, Јавни натписи са грешкама у настави правописа у основној школи (од 5. до 8. разреда), у: Ј. Милинковић, Б. Требјешанин (ур.), Имплементација иновација у образовању - изазови и дилеме (457-471), Београд: Учитељски факултет.

Шипка 2011: М. Шипка, Култура говора, Нови Сад: Прометеј.

\title{
ИЗВОРИ
}

Дневни лист Вечерње новости, 28. 7. 2007, 19.

Дневни лист Политика, 01. 10. 1928, 1.

\author{
Goran N. Zeljić \\ ORTHOGRAPHIC KNOWLEDGE OF FUTURE PRIMARY AND PRESCHOOL \\ TEACHERS
}

Summary

This paper analyzes the results of the orthographic assignments achieved during entrance examinations at the Teacher Education Faculty in Belgrade in 2013-2014. Using a sample of a total of 1100 candidates that took examination for one of two modules (the primary and preschool teachers), we have examined the extent to which the high school graduates known the orthographic norm. We considered the entrance tests in Serbian language and literature. The research is carried out to establish the connection between the orthographic rules learning, and the impact of spoken and written practice that the speakers of one language have. The mistakes analysis has shown that high school graduates had problems when they needed to apply more orthographic rules in a broader context, such as a clause. The research results point out that it is necessary to change approaches to teaching contents of orthography at all age levels by moving 
the focus from understanding and applying individual orthographic rules to the development of a deeper understanding and integration of the various components of orthographic knowledge.

Key words: Serbian language, Serbian language teaching, orthographic norm, orthography. 